\title{
SINTESIS XANTON DARI ASAM 2-PHENOXYBENZOIC ACID SEBAGAI BAHAN DASAR OBAT MALARIA BARU
}

\section{SYNTHESIS OF XANTON FROM 2-PHENOXYBENZOIC ACID AS A BASE MATERIAL FOR NEW MALARIA DRUGS}

\author{
Amanatie $^{1)}$, Jumina ${ }^{2)}$, Mustofa $^{3)}$, dan M. Hanafi ${ }^{4)}$ \\ ${ }^{1)}$ Kimia-FMIPA Universitas Negeri Yogyakarta, Jl.Colombo No.1, Yogyakarta 55281 \\ ${ }^{2)}$ Kimia-FMIPA Universitas Gadjah Mada, Jl. Bulaksumur Yogyakarta \\ ${ }^{3)}$ Fakultas Kedokteran Universitas Gadjah Mada, Jl. Bulaksumur Yogyakarta \\ 4) Pusat Penelitian Kimia-LIPI, Kawasan PUSPIPTEK Serpong, Tangerang Selatan, Banten 15314 \\ Email : amanatie_ama@yahoo.com
}

Diterima : 19 Agustus 2013, Direvisi : 10 September 2013, Disetujui : 12 Oktober 2013

\begin{abstract}
ABSTRAK
Telah dilakukan sintesis xanton dari bahan dasar asam 2-phenoxybenzoic acid melalui reaksi siklisasi terkatalisis asam sulfat. Produk yang dihasilkan dikarakterisasi dengan spektrometer UVvis, FT- IR, ${ }^{1} \mathrm{H}-\mathrm{NMR},{ }^{13} \mathrm{C}-\mathrm{NMR}$ dan LCMS. Siklisasi asam 2-fenoksibenzoat dengan asam sulfat pekat menghasilkan xanton dengan persen berat $86,11 \%$. Senyawa ini dipakai sebagai bahan dasar untuk membuat obat malaria.
\end{abstract}

Kata kunci : 2-phenoxybenzoic acid, Sintesis, Xanthone, Karakterisasi

\begin{abstract}
Synthesis of xanthone was conducted from the raw material of 2-phenoxybenzoic acid through acid-catalyzed-cyclization. The product was characterized using UV-Vis, $F T-I R,{ }^{1} H-N M R,{ }^{13} C-N M R$, and $L C-M S$. Cyclization of 2-phenoxybenzoic acid using sulfuric acid catalyt gave xanthone in $86.11 \%$ yield. These compounds as the basis of new malaria drugs.
\end{abstract}

Keywords : 2-phenoxybenzoic acid, Synthesis, Xanthone, Characterized.

\section{PENDAHULUAN}

Malaria masih merupakan masalah baik di negara-negara berkembang maupun maju. Usaha pemberantasan penyakit malaria telah lama dilakukan dengan berbagai cara, namun hingga kini belum memberikan hasil seperti yang diharapkan. Bahkan malaria merupakan salah satu penyakit yang mengancam penduduk di seluruh dunia. Hal ini ditandai dengan meningkatnya kasus malaria di seluruh daerah endemik di dunia $^{(1)}$.

Banyak faktor yang menjadi kendala dalam usaha pemberantasan penyakit malaria. Kendala utama tersebut adalah timbulnya vektor malaria (nyamuk) yang resisten terhadap insektisida, dan parasit malaria yang resisten terhadap obat antimalaria. Parasit malaria yang resisten ini cepat menyebar hampir di seluruh daerah endemik malaria di dunia. 
Munculnya parasit malaria, khususnya Plasmodium falciparum yang resisten terhadap antimalaria khususnya klorokuin menyebabkan antimalaria menjadi tidak efektif lagi. Di samping itu, Badan Kesehatan Dunia (World Health Organization, WHO) menargetkan penurunan kasus dan kematian akibat malaria sebesar $50 \%$ atau lebih pada tahun 2000-2010 dan 75\% atau lebih antara tahun 2000-2015 (2). Hal ini mendorong para peneliti untuk menemukan antimalaria baru guna mengatasi resistensi tersebut. Salah satu strategi dalam penemuan antimalaria baru adalah dengan mengembangkan senyawa aktif dari tanaman obat yang secara tradisional digunakan oleh masyarakat untuk mengobati malaria ${ }^{(3)}$.

Struktur (Gambar 1) dan aplikasi senyawa xanton telah banyak dilaporkan, akan tetapi pemanfaatannya sebagai antimalaria belum banyak dilaporkan.

Usaha untuk menemukan anti malaria baru dapat dilakukan melalui beberapa cara, diantaranya dengan a). sintesis senyawa yang mampu menghambat metabolism spesifik parasit, b). isolasi senyawa aktif dari bahan alam yang secara tradisional digunakan untuk mengobati malaria, dan c). sintesis senyawa dengan struktur kimia yang mirip dengan senyawa yang telah diketahui aktivitas anti malarianya. ${ }^{(4)}$

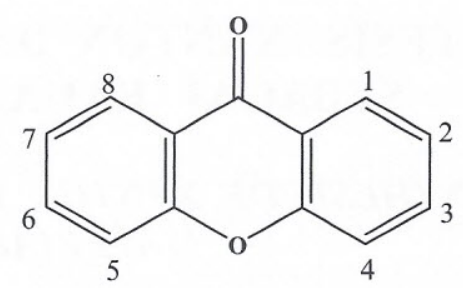

Gambar 1. Kerangka dasar senyawa xanton dan penomorannya

Penelitian ini telah diawali dengan melakukan isolasi dan identifikasi senyawa xanton dari akar G. dulcisserta uji aktivitasnya sebagai antimalaria (5). Namun, hasil yang diperoleh sangat sedikit, sehingga peneliti berusaha mencari dan mencoba cara untuk mendapatkan senyawa murni dalam jumlah yang banyak. Oleh karena itu, peneliti melakukan sintesis senyawa xanton sebagai bahan dasar pembuatan obat malaria baru.

Beberapa senyawa turunan xanton dilaporkan memiliki aktivitas $\operatorname{antimalaria}^{(6)}$. Senyawa ini secara selektif dapat menghambat pertumbuhan $P$. falciparum dalam kultur.

Xanton umumnya diperoleh dari isolasi bahan alam. Isolasi senyawa xanton dari daun $G$. dulcis telah dilakukan oleh Kosela $\mathrm{dkk}^{(7)}$, dan dari kulit batang $G$. dulcis telah dilakukan oleh Hanafi dkk ${ }^{(8)}$. Likhitwitayawuid $\mathrm{dkk}^{(9)}$ telah menemukan senyawa xanton baru dari G. cowa yang dikenal dengan 7-O-metilgarcinon-E yang dikenal sebagai obat malaria tradisional, mempunyai $\mathrm{IC}_{50} 1,50-3,00 \mu \mathrm{g} / \mathrm{mL}$. Dari 
C.Caledonicum telah ditemukan senyawa xanton baru yaitu 1,3,7 trioksigen dan prenil xanton yang sangat poten dengan $\mathrm{IC}_{50}=1,0 \mu \mathrm{g} / \mathrm{mL}$ oleh Hay $\mathrm{dkk}^{(\mathbf{1 0})}$. Amanatie, $\mathrm{dkk}^{(11)}$ telah melaporkan nilai $\mathrm{IC}_{50}$ sebesar15,21 $\mu \mathrm{g} / \mathrm{mL}$ untuk ekstrak dari akar Garcinia dulcis. Di lain pihak, sintesis senyawa xanton umumnya dilakukan dari turunan asam salisilat dengan turunan fenol melalui satu tahap atau melalui jalur benzofenon maupun diaril eter ${ }^{(\mathbf{1 2}, \mathbf{1 3})}$. Sedangkan, proses sintesis xanton dari bahan dasar asam 2-fenoksi benzoat dengan siklisasi terkatalis asam sulfat sampai saat ini belum dilaporkan oleh peneliti sebelumnya. Penelitian ini bertujuan untuk mensintesis dan mengkarakterisasi xanton dari bahan dasar asam 2-fenoksibenzoat. Penelitian ini untuk mensintesis xanton yang dapat dipakai sebagai bahan dasar pembuatan obat malaria baru. Dalam pengembangan ilmu pengetahuan dan teknologi, hasil penelitian ini dapat memberikan sumbangan pemikiran untuk menambah khasanah pengetahuan terutama dalam usaha untuk pembuatan obat malaria baru.

\section{BAHAN DAN METODA}

\section{Bahan}

Bahan yang digunakan untuk sintesis, ekstraksi, Kromatografi Lapis Tipis (KLT), Kromatografi kolom dan rekristalisasi, berupa bahan baku, pelarut yang meliputi: Senyawa asam 2-fenoksi benzoat (Merck), asam sulfat pekat (Merck), $\mathrm{Na}_{2} \mathrm{SO}_{4}$ anhidrous (Merck), $\mathrm{NaOH}$ (Merck), metanol p.a (Merck), etil asetat (Merck), diklorometana (Merck), asam asetat (Merck), dan akuades.

\section{Peralatan}

Alat yang digunakan untuk keperluan dalam reaksi kimia, pemisahan, pemurnian, meliputi: seperangkat alat refluks, seperangkat alat destilasi, pompa vakum, corong pisah, pemanas listrik, magnit stirer, seperangkat KLT, lampu UV, rotary evaporator Buchi, seperangkat alat kromatografi kolom, batang pengaduk, desikator dan alat-alat gelas laboratorium.

Alat untuk karakterisasi produk reaksi meliputi alat penentuan titik lebur electrothermal 9100, spektrometer Inframerah (FTIR 8201 Shimadzu PC), spektrometer proton resonansi magnetik inti ( ${ }^{1}$ HNMR JOEL, JNM MYGO 60 MHz, ${ }^{1}$ HNMR JOEL, JNM ECA 500 $\mathrm{MHz}$ ) dan LC-MS.

Prosedur seperti yang dijelaskan pada paten No: (51) I.P.C: A 61 K31/01,A 61 31/03,A 61K 31/0,75,A 61K 31/12 dengan nomor pendaftaran P00201100067 pada tanggal 24 Januari 2011 dengan judul invensi proses dan produk pembuatan trihidroksi xanton dari bahan dasar asam 2-phenoksi benzoat sebagai bahan untuk 
obat malaria diajukan oleh Amanatie, $\mathrm{dkk}^{(14)}$.

\section{HASIL DAN PEMBAHASAN}

\section{Sintesis xanton}

Senyawa xanton disintesis melalui reaksi siklisasi senyawa asam 2fenoksibenzoat terkatalisis asam. Produk yang diperoleh berbentuk seperti kristal jarum putih kekuningan dengan persen hasil $86,11 \%$ dan titik lebur 173,5$173,9^{\circ} \mathrm{C}$. Nilai titik leleh produk siklisasi mendekati titik leleh senyawa xanton teoritis, yakni $172-174^{\circ} \mathrm{C}$. Kebenaran struktur produk dapat dibuktikan dengan analisis menggunakan spektrometer UVVis, FT-IR, NMR, dan Liquid Chromato graphy-Mass Spectrometer (LC-MS).

Senyawa produk sintesis dianalisis dengan spektrofotometer UV-Vis dan diperoleh empat panjang gelombang maksimum yaitu 334,$0 ; 258,5 ; 236,0$ dan 202,5 nm seperti yang disajikan pada Gambar 2.

Spektrum UV-Vis produk xanton dari asam 2-fenoksibenzoat tersebut mendekati dengan yang dikemukakan oleh Harborne $^{(15)}$, dengan serapan pada daerah 230-245, 250-265 dan 305-330 nm. Oleh karena itu, dapat diindikasikan bahwa produk siklisasi asam 2-fenoksi benzoat terkatalisis asam sulfat adalah senyawa xanton.

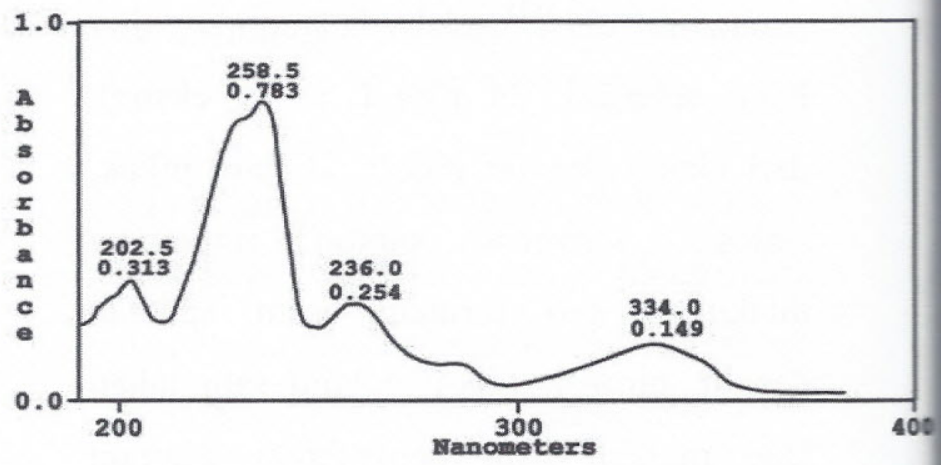

Gambar 2. Spektrum UV-Vis Xanton

Spektrum IR (KBr) pada Gambar 3 dari senyawa hasil siklisasi asam 2fenoksibenzoat menunjukkan puncakpuncak karakteristik. Serapan kuat pada $1654 \mathrm{~cm}^{-1}$ menunjukkan gugus karbonil $(\mathrm{C}=\mathrm{O})$. Puncak pada 1604 dan $2931 \mathrm{~cm}^{-1}$ menunjukkan gugus $\mathrm{C}=\mathrm{C}$ dan $\mathrm{C}-\mathrm{H}$ aromatik. Daerah 1005-1141 $\mathrm{cm}^{-1}$ mengindikasikan adanya gugus eter aromatik (Ar-O-Ar). Berdasarkan spektrum FT-IR, dapat dikatakan bahwa senyawa hasil sintesis mempunyai gugus karbonil, $\mathrm{C}=\mathrm{C}, \mathrm{C}-\mathrm{H}$ aromatik, dan eter aromatik sehingga senyawa ini diperkirakan mempunyai kerangka dasar senyawa xanton. 


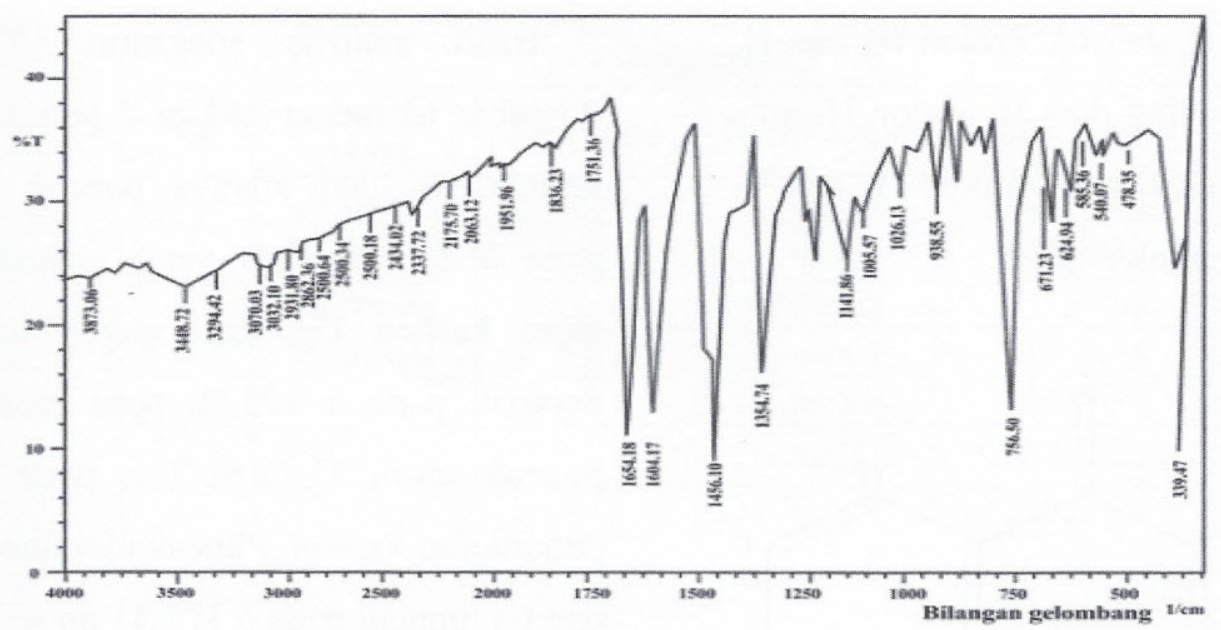

Gambar 3. Spektrum IR (KBr) Xanton

Spektrum ${ }^{1} \mathrm{H}-\mathrm{NMR} \quad($ Gambar 4) menunjukkan adanya empat puncak yang menggambarkan empat jenis proton dan berada pada daerah serapan cincin benzena. Hasil analisis ${ }^{1} \mathrm{H}-\mathrm{NMR}$ menunjukkan bahwa puncak $\mathrm{H}_{1}$ dan $\mathrm{H}_{8}$ muncul pada $\delta_{\mathrm{H}}=8,28 \mathrm{ppm}$ (doublet, $J=7.65)$.

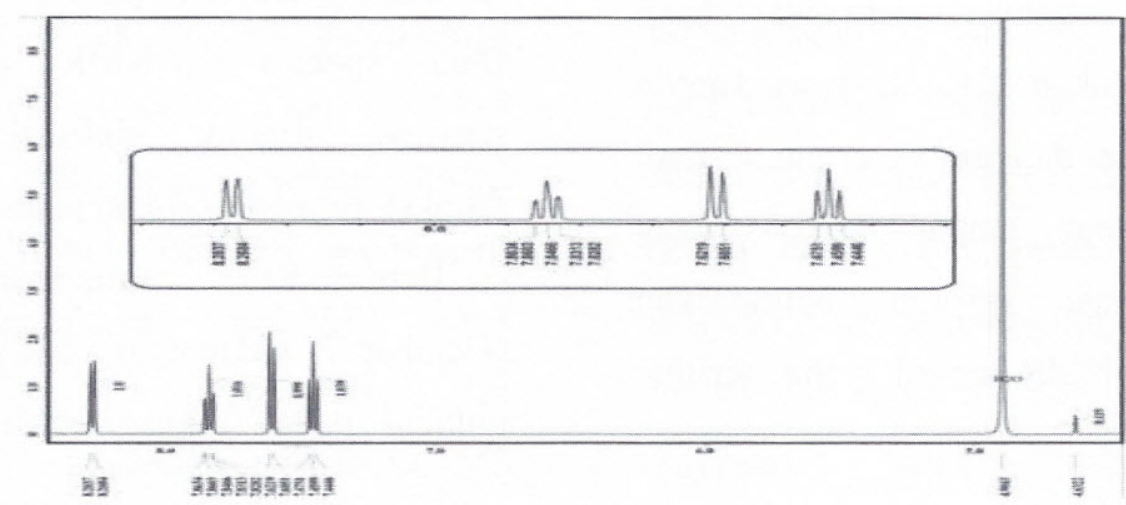

Gambar 4. Spektrum ${ }^{1}$ H-NMR Xanton, Pergeseran kimia ( $\left.\delta\right)$

Berdasarkan perkiraan struktur senyawa xanton, proton $\mathrm{H}_{1}$ dan $\mathrm{H}_{8}$ bersifat equivalen dengan pergeseran kimia yang paling besar karena terkonjugasi (beresonansi) dengan gugus karbonil $\mathrm{C}=\mathrm{O}$. Proton $\mathrm{H}_{1}$ dan $\mathrm{H}_{8}$ berinteraksi dengan proton $\mathrm{H}_{3}$ dan $\mathrm{H}_{6}$, sehingga menghasilkan puncak doublet. Puncak $\mathrm{H}_{2}$ dan $\mathrm{H}_{7}$ muncul pada $\delta_{\mathrm{H}}=7,86 \mathrm{ppm} \quad(t, J=7.65)$. Proton
$\mathrm{H}_{2}$ dan $\mathrm{H}_{7}$ berinteraksi dengan proton $\mathrm{H}_{1}$ dan $\mathrm{H}_{8}$ serta proton $\mathrm{H}_{3}$ dan $\mathrm{H}_{6}$ dimana konstanta kopling $J_{\mathrm{H}-2, \mathrm{H}-1}$ atau $J_{\mathrm{H}-7, \mathrm{H}-8}$ sama besarnya dengan $J_{\mathrm{H}-2, \mathrm{H}-3}$ atau $J_{\mathrm{H}-}$ 7,H-6 sehingga multiplisitasnya adalah triplet. Puncak $\mathrm{H}_{4}$ dan $\mathrm{H}_{5}$ munculpada $\delta_{\mathrm{H}}=7,62 \mathrm{ppm}(d, J=8.4)$. Proton ini mengalami kopling dengan $\mathrm{H}_{3}$ dan $\mathrm{H}_{6}$. Atom $\mathrm{H}_{3}$ dan $\mathrm{H}_{6}$ memberikan serapan pada 
$\delta_{\mathrm{H}}=7,47$ ppm $(t, J=7.6)$. Proton $\mathrm{H}_{3}$ dan $\mathrm{H}_{6}$ mengalami kopling dengan proton $\mathrm{H}_{4}$ atau $\mathrm{H}_{5}$ serta kopling dengan proton $\mathrm{H}_{2}$ dan $\mathrm{H}_{7}$ sehingga berbentuk triplet.<smiles>O=c1c2ccccc2oc2ccccc12</smiles>

Gambar 5. Perkiraan jenis proton (d doublet, $\mathrm{t}$ triplet)

Hasil analisis spektrum ${ }^{1} \mathrm{H}-\mathrm{NMR}$ menunjukkan bahwa senyawa hasil sintesis merupakan suatu senyawa xanton dengan adanya dua gugus aromatik/fenil karena terdapat empat proton yang simetris.Perkiraan proton berdasarkan spektrum ${ }^{1} \mathrm{H}-\mathrm{NMR}$ Seperti yang terlihat pada Gambar 5.
Hasil analisis spektrum ${ }^{13} \mathrm{C}-\mathrm{NMR}$ (Gambar 6) menunjukkan 7 puncak atom karbon. Terlihat adanya puncak karbon pada $\delta$ 179,01 ppm yang menunjukkan atom karbon $\mathrm{C}_{13}$ dari gugus karbonil. Serapan pada $\delta 122,78$ ppm merupakan puncak atom $\mathrm{C}_{9}$ dan $\mathrm{C}_{12}$ pada sistem penomoran xanton. Puncak atomkarbon $\mathrm{C}_{1}$ dan $\mathrm{C}_{8}$ muncul pada $\delta 127,41 \mathrm{ppm}$. Puncak atom karbon $\mathrm{C}_{2}$ dan $\mathrm{C}_{7}$ memberikan serapan pada 119,42 ppm. Puncak atom karbon $\mathrm{C}_{3}$ dan $\mathrm{C}_{6}$ beradapada $\delta 125,48$ ppm. Puncak.atom karbon $\mathrm{C}_{4}$ dan $\mathrm{C}_{5}$ beradapada $\delta 136,78 \mathrm{ppm}$ dan puncak karbon $\mathrm{C}_{10}$ dan $\mathrm{C}_{11}$ pada $\delta 157,82 \mathrm{ppm}$. Data spektra ${ }^{1} \mathrm{H}-\mathrm{NMR}$ dan ${ }^{13} \mathrm{C}-\mathrm{NMR}$ senyawa produk siklisasi asam 2fenoksibenzoat disajikan pada Tabel 1 .

Berdasarkan kromatogram LC (Gambar 7) didapatkan satu puncak yang muncul pada waktu retensi 4,6 menit.

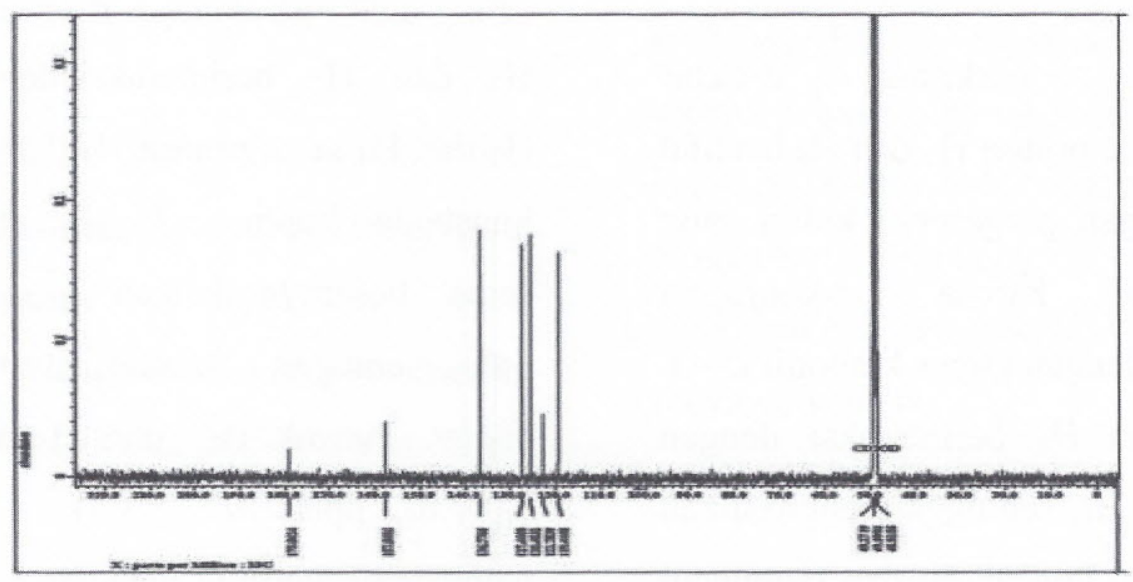

Pergeseran kimia $(\delta)$

Gambar 6. Spektra ${ }^{13} \mathrm{C}$-NMR Xanton 
Tabel 1. Data Spektra ${ }^{1} \mathrm{H}-\mathrm{NMR}{ }^{13} \mathrm{C}-\mathrm{NMR}$ Xanton

\begin{tabular}{|c|c|c|c|c|}
\hline No & $\begin{array}{l}\text { Posisi } \\
\text { Atom }\end{array}$ & $\delta H(p p m)$ & Posisi Atom & $\delta \mathrm{C}(\mathrm{ppm})$ \\
\hline 1 & $\mathrm{H}_{1}$ danH $_{8}$ & $8,3, \mathrm{~d}$ & $\mathrm{C}_{1}$ danC $_{8}$ & 127,4100 \\
\hline 2 & $\mathrm{H}_{2}$ dan $\mathrm{H}_{7}$ & $7,8, \mathrm{t}$ & $\mathrm{C}_{2}$ danC $_{7}$ & 125,4832 \\
\hline 3 & $\mathrm{H}_{4}$ dan $\mathrm{H}_{5}$ & $7,6, d$ & $\mathrm{C}_{4}$ danC $_{5}$ & 136,7766 \\
\hline 4 & $\mathrm{H}_{3}$ dan $_{6}$ & $7,4, \mathrm{t}$ & $\mathrm{C}_{3}$ danC $_{6}$ & 119,4168 \\
\hline 5 & & & $\mathrm{C}_{9}$ dan $\mathrm{C}_{12}$ & 122,7839 \\
\hline 6 & & & $\mathrm{C}_{10}$ dan $\mathrm{C}_{11}$ & 157,8182 \\
\hline 7 & & & $\mathrm{C}_{13}$ & 179,0124 \\
\hline
\end{tabular}

Selanjutnya puncak tersebut dianalisis dengan MS untuk mengetahui massa molekul produk. Produk yang dianalisis menggunakan LC-MS (metode ESI-MS ion positif) mengalami fragmentasi.

Metode ESI-MS memudahkan untuk menentukan puncak dari ion molekulnya (BM) karena puncak ion molekul mempunyai kelimpahan paling tinggi (base peak).Metode ESI-MS ion posi-tif akan mengarahkan molekul untuk membentuk ion $[\mathrm{M}+\mathrm{H}]^{+},[\mathrm{M}+\mathrm{Na}]^{+}$, dan $[\mathrm{M}+\mathrm{K}]^{+(16)}$. Interpretasi hasil LC-MS metode ESI-MSmudah dilakukan karena puncak-puncak yang dihasilkan tidak bercampur dengan puncak-puncak senyawa pengotor yang tercampur dalam hasil sintesis ${ }^{(17)}$. Hasil spektrum ESI-MS menunjukkan beberapa puncak (Gambar 8) yaitu puncak (a) dengan $m / z=179,37$ menunjukkan ion molekul $\left[\mathrm{M}+\mathrm{H}-\mathrm{H}_{2} \mathrm{O}\right]^{+}$ yang memiliki intensitas sangat rendah sekitar 3\%. Puncak (b) dengan $\mathrm{m} / \mathrm{z}=$ 197,23 adalah ion molekul $[\mathrm{M}+\mathrm{H}]^{+}$ dengan intensitas paling tinggi yaitu 98\%. Puncak ini sesuai dengan berat molekul senyawa xanton yaitu 196.

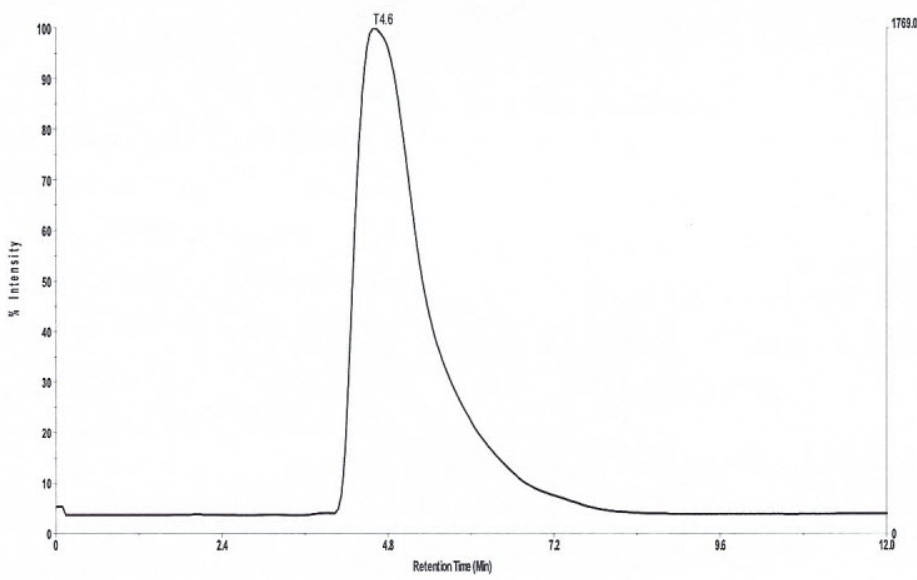

Gambar 7. Kromatogram Liquid Chromatography Xanton 
Puncak (c) dengan $m / z=198,23$ berasal dari $[\mathrm{M}+2 \mathrm{H}]^{+}$dan memiliki intensitas rendah sekitar $15 \%$. Puncak (d) dengan $m / z=235,13$ yaitu $[\mathrm{M}+\mathrm{K}]^{+}$dengan intensitas sangat rendah sekitar 2,5\%. Puncak (e) dengan $\mathrm{m} / \mathrm{z}=283,19$ memiliki intensitas sangat rendah sekitar $1 \%$, yang berasal dari ion $[\mathrm{M}+\mathrm{K}+\mathrm{Li}+\mathrm{ACN}]^{+}$. Puncak (f) dengan $m / z=414,88$ dengan intensitas sedang sekitar $23 \%$ adalah puncak dari $[2 \mathrm{M}+\mathrm{Na}-\mathrm{H}]^{+}$. Puncak $(\mathrm{g})$ dengan $m / z=415,87$ dengan intensitas rendah sekitar $5 \%$ merupakan ion [2M + $\mathrm{Na}]^{+}$.

Mekanisme reaksi siklisasi asam-2fenoksibenzoat menghasilkan xanton disajikan pada Gambar 9.

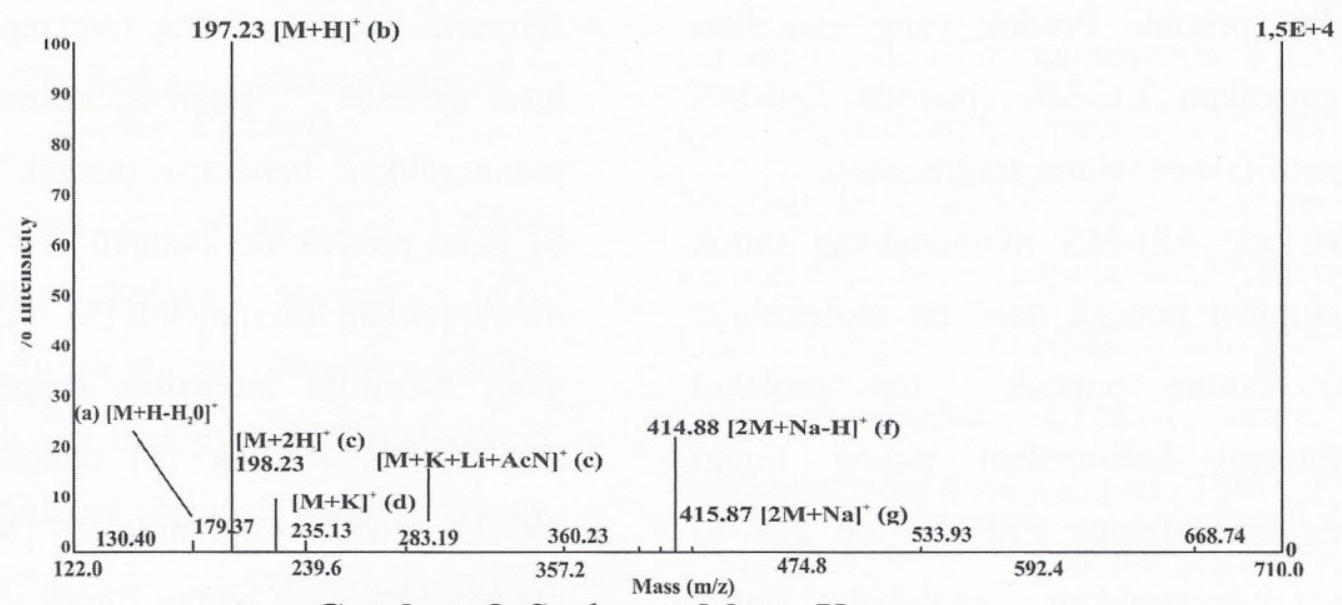

Gambar 8. Spektrum Massa Xanton

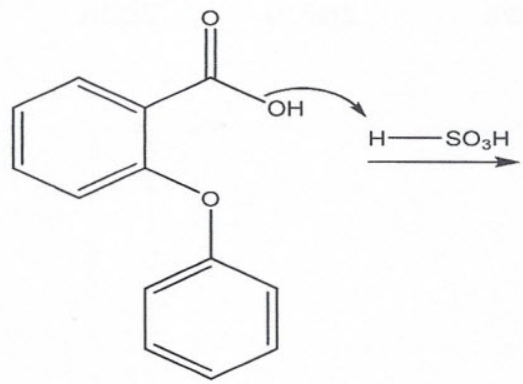<smiles>O=Cc1ccc(-c2ccccc2)cc1Oc1ccccc1</smiles>

Asam 2-fenoksibenzoat (1)<smiles>O=c1c2ccccc2oc2ccccc12</smiles>

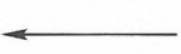<smiles>O=C1CCCc2ccccc2Oc2ccccc21</smiles>

Gambar 9. Mekanisme reaksi sintesis xanton 


\section{UCAPAN TERIMA KASIH}

Pada kesempatan ini team peneliti menghaturkan uicapan terima kasih kepada DIKTI Program Hibah Penelitian Doktor 2009.

\section{KESIMPULAN}

Berdasarkan hasil dan pembahasan yang telah dijelaskan pada bagian sebelumnya, dapat disimpulkan bahwa: Siklisasi terkatalisis asam terhadap asam 2-fenoksi benzoat menghasilkan senyawa xanton dengan rendemen $86,11 \%$.

\section{DAFTAR PUSTAKA}

1. WHO (2008) World Malaria report 2008. WHO, Geneva.

2. WHO (2009) World Malaria report 2009. WHO, Geneva.

3. Mustofa, (2009) Malaria antara harapan dan kenyataan, Pidato Pengukuhan Guru Besar Universitas Gadjah Mada, Yogyakarta.

4. Sholikah, E.N., Wijayanti, M.A., Hadanu, R., Supargiyono, Jumina and Mustofa, (2007) In Vitro Antiplasmodial Activity and Cytotoxicity of New N-Benzyl-1,10 phenanthroline Derivatives, Proceeding of International Conference on Chemical Sciences (ICCS-20070: Jointly held by Department of Chemistry Gadjah Mada University and Department of Chemistry, Universiti Sains Malaysia, Yogyakarta,24-26 May 2007, 258-263.

5. Amanatie, Jumina, Mustofa, Suharto dan Siswani, E.D., (2005) Isolasi dan derivatisasi kom- ponen senyawa xanton dari akar Garcinia dulcis sebagai Anti malaria, Laporan Penelitian Pekerti Tahun II, Lembaga Penelitian Universitas Negeri Yogyakarta, Yogyakarta.

6. Likhitwitayawuid, K., Chanmahasathien W., Ruang rungsi, N. dan Krungkrai, J., (2000) Antimalarial xanthones from Garcinia cowa, Plant. medic., 64: 70-72.

7. Kosela, S., Hu, I.H., Rahmatia, T., Hanafi, M.dan Sim, K.Y., (2000) Dulxanthones $\mathrm{F}-\mathrm{H}$, three new pyranoxanthones from Garcinia dulcis. J.Nat. Prod, 63, 406-407.

8. Hanafi, M., Soemiati, A., Kosela, S. dan Leslie, J.H., (2004) Identification and cytotoxic L1210 cell evaluation of prenylated pyranoxanthonoids from Garcinia dulcis fruit (Gutteferae) nHexane Extract. Prosiding Seminar Interna- tional UGM, Yogyakarta.

9. Likhitwitayawuid, K., Phadungcharosen, T. and Krungkrai, J., (1997) 7-o -Methylgarcinone E from Garcinia cowa, Phytochem., 45 (6), 1299-1301.

10. Hay, A.E., Helesbeux, J.J., Duval, O., Labaied, M., Grellier, P. and Richomme, P., (2004) Antimalarial xanthone from Calophylum caledonicum and Garcini viellardii, Life Sci., 75, 3077-3085.

11. Amanatie, Jumina, Mustofa dan Hanafi, M., (2009) Sintesis dan uji aktivitas antimalaria secara in vitro pada tri-hidroksixanton, Laporan Penelitian Hibah Doktor, LPPM-UGM, 2009, Universitas Gadjah Mada, Yogyakarta.

12. Naidoo, J.M., (2009) Novel Methodology for The Synthesis of Xanthones, Tesis, University Withwatersrand, Johannesburg. 
13. Fonteneau, N., Martin, P., Mondon, M., Ficheux, H., and Gesson, J.P., (2001) Synthesis of quinine and xanthone analogs of rhein, Tetrahedron, 57, 9131-9135.

14. Amanatie dan Jumina, (2011) Proses dan produk pada pembuatan trihidroksixanton dari bahan dasar asam 2-fenoksibenzoat sebagai bahan obat antimalaria baru, Paten, terdaftar di Dit Jen HKI No P00201100067.

15. Harborne, J.B., (1987) Metode Fitokimia, Penuntun Cara Modern Menganali sis Tumbuhan, ter-jemahan
Kosasih Padmawinata dan Iwang Soediro, ITB Bandung.

16. Eichorn, $P$ and Knipper, Thomas $P$, (2001) Electrospray ionization mass spectrosmetric studies on the ampho teric surfactant cocomido propy betaine journal of mass spectro metry, J.Mass Spectrom, 36: 677-684.

17. Julianus, J., (2006) Sintesis dan Uji Aktivitas Diaseti Pentagamavunon l, Tesis Sekolah Pasca Sarjana FMIPA UGM. Yogyakarta. 